\title{
Problems of Drinking Water Quality in the Western Regions of Ukraine
}

\author{
Nataliia Huliieva, Viktoriia Pasternak \\ Lutsk National Technical University, 43018, Lutsk, Volyn region, Ukraine
}

doi: https://doi.org/10.21467/abstracts.93.18

\begin{abstract}
Today one of the most pressing problems of technogenic disposition in the Western regions of Ukraine is drinking water. Use clean drinking water we preserve the health and life of people in General. Failure to comply with the quality standards of drinking water leads to adverse short-and long-term consequences for health and well-being of the population. Two thirds of Ukrainians of the Western regions consume water from surface waters and one third from groundwater. Lately the quality of drinking water deteriorates in Ukraine and around the world. The reasons are: radioactive contamination; increased water use; anthropogenic impact; agriculture; energy; metallurgy, chemical, oil refining industry etc. Especially dangerous contaminants of water are petroleum products, pesticides, radionuclides, heavy metals (lead, mercury, copper and iron), etc. [1]. To the Western regions of Ukraine consists of seven regions: Lviv, Ivano-Frankivsk, Zakarpattia, Rivne, Ternopil, Volyn and Chernivtsi. Relatively clean considered IvanoFrankivsk, Zakarpattia, Rivne, Ternopil, Volyn and Chernivtsi region. Lviv region suffers from pollution of underground waters, Ivano-Frankivsk and Chernivtsi from pollution of surface. The radioactive contamination suffers Volyn and Chernivtsi. Polluted are the cities: Lviv, Kherson, Lutsk and Rivne. The consequence of contamination is anthropogenic load. Anthropogenic pollution of water sources due to the huge emissions of untreated water from industrial enterprises and sewage. According to experts, is cleaned not more than 30 percent of all the water. A huge amount of harmful substances: heavy metals, pesticides, waste chemicals discharged into the river, first and foremost, in Pripyat, Styr, Goryn, Western Bug, Dniester. On these rivers there are more than 10 major cities and industrial centers, about 3 thousand enterprises, more than three hundred communal farms. Only sewer systems of the cities of Lviv and Lutsk annually discharge wastewater in accordance 159.8 and 84.9 million $\mathrm{m}^{3}$. The consequences of the pollution of the rivers is not enough the cleared sewage are: strong odor, specific mucus, as a consequence - the extinction of river fauna, in particular, reducing the number of fish for the destruction of fodder and breeding grounds, the almost complete disappearance of cancers, the complete disappearance of one type of insect. In General, the discrepancy between water content of nitrate was in fact in all areas of the Western region, which adversely affects the health of residents, especially children. Long-term consumption of drinking water contaminated with nitrates, contributes to gastrointestinal diseases and disorders of the immune system and is one of the factors in the incidence of the cardiovascular system. The main causes of contamination of well water is close to the location of the wells to roads, buildings and sewage networks, septic tanks, warehouses of fertilizers and pesticides, wireline, places, cattle and other contamination of soil and groundwater, and improper construction of wells and the surrounding area or improper maintenance, contamination of soil and aquifers waste liquid, failure periodic cleaning from silt and disinfecting wells and the like. Also on the quality of water affects the amount and frequency of precipitation, and the overall environmental situation in the region. Precipitation in the form of rain carrying undissolved particles: dust, volcanic ash, pollen, bacteria, fungi, and sometimes larger microorganisms. The ocean is a source of
\end{abstract}

(C) 2020 Copyright held by the author(s). Published by AIJR Publisher in "Abstracts of The Second Eurasian RISK-2020 Conference and Symposium" April 12- 19, 2020, Tbilisi, Georgia. Jointly organized by AMIR Technical Services LLC, Georgian Technical University, Institute of Geography (Kazakhstan) and Russian Institute of Petroleum Geology and Geophysics.

DOI: $10.21467 /$ abstracts.93 
The Second Eurasian RISK-2020 Conference and Symposium

pollution rainwater various salts: chloride, sulfate, sodium, magnesium, calcium and potassium. Industrial emissions pollute precipitation, mainly due to the organic solvents of the nitrogen and sulfur oxides, which cause deposition of "acid rain". Chemicals used in agriculture have a negative impact on water quality. Thus, the quality of drinking water is a critical factor of human life. It is necessary to further develop and implement measures to improve water quality for the population, taking part in the creation of projects to improve the environment and to prevent technogenic disasters.

Assessment of drinking water quality in Ukraine is determined according to SSNR 2.1.3.2630-10 [2]. The consumption of drinking water from artesian and surface sources of centralized and decentralized water supply to ensure that the necessary filters are used in modern resource-saving and energy-saving purification technology based on natural and artificial materials. In particular, granular materials using activated carbon or their analogues are graphite sorbents, using natural minerals as a filter material (saponites, zeolites, clinoptilolites, etc.) [3]. They have the ability to delete from the source water $93-96 \%$ carcinogenic, anthropogenic compounds, petroleum products, detergents, pesticides, chlorinated and organic compounds. The most effective method of drinking water purification is the method of using the powder of permeable materials based on natural minerals - saponite [4]. The raw materials of natural mineral saponiteacquire on Taskivske and Varvarivske fields Khmelnitsky region (Ukraine).

The sorption capacity of granular saponite is large enough: $60-200 \mathrm{mg} / \mathrm{g}$, so they can be used for purification and purification of liquids. The mineral is also widely used for the purification of metal ions, for example, for the purification of galvanic effluents of heavy metal ions. At initial concentrations of heavy metal ions in $\left(\mathrm{mg} / \mathrm{dm}^{3}\right)$ : copper - 38.5; nickel - 0.37; iron - 87.5; trivalent chromium - 9.6; hexavalent chromium 2.1. After purification, the concentrations of metals in the purified water are found in small quantities and lie within the allowable level. The consumption of saponite powder is $2 \mathrm{~kg} / \mathrm{m}^{3}$. The volatile organic matter from the saponite is removed by high-temperature desorption with air $\left(120-140{ }^{\circ} \mathrm{C}\right)$, steam $\left(200-300{ }^{\circ} \mathrm{C}\right)$ or flue gases $\left(300-500^{\circ} \mathrm{C}\right)$. Regeneration after absorption of heavy metals is carried out by heating in a stainless steel reactor at a temperature of $300^{\circ} \mathrm{C}$ for $4 \mathrm{~h}$ in an air stream.

Saponite - titanium porous permeable materials made at the Lutsk National Technical University by powder metallurgy methods. Important steps in the manufacture of materials are the selection of the ratio of the charge, the mode of pressing, sintering (by the method of self-propagating high-temperature synthesis (SHS)), cooling rate, thermal effect with the required preset structure and morphology of open pores to obtain the required permeability, chemical, mechanical and thermal resistance. This technology of saponite - titanium powder permeable materials allows purification of drinking water according to SSNR with less financial cost than titanium filters [5].

\section{References}

1. Gulieva, N., Rud', V. Problems while providing ecoclean drinking water for population living on territories contaminated radioactively. Actual Problems of Economics: Scientific economic journal. Kyiv, (2011), 10(124), 194-202.

2. SSNR 2.1.3.2630-10. On approval of the State sanitary norms and regulations "Hygienic requirements for drinking water intended for human consumption" Order of the MOH of Ukraine of May 12, 2010 No. 400. Registered with the Ministry of Justice of Ukraine on July 1, 2010 under No. 452/17747.

3. Spivak, V., Astrelin, I., Tolstopalova, N., Atamaniuk. I. Ecological sorbent which is mainly consist of saponite mineral from Ukrainian clay-field. Chemistry \& Chemical Technology. (2012), 6(4), 455-457.

4. Guliieva, N. The filtration efficiency of porous permeable materials of saponite - titanium system composite. Metallurgical and Mining Industry. (2016), 4, 97-99.

5. Increase in homogenization of bidisperse mixture of spongy titanium powders and reduction in energy consumption during its preparation in the production of thin permeable elements/ V.V. Savich, A.M. Taraykovich, G.A. Sheko and S.A. Bedenko// EURO PM2017 Metal Powder Report, 72(5), September/October, 2017, 327-330. 